\title{
THE UTILIZATION OF GOLDEN PERIOD OF ISCHEMIC STROKE IN PATIENTS IN PRODUCTIVE AGES
}

\author{
Vidya Tri Huttami ${ }^{1}$, Atik Choirul Hidajah ${ }^{1}$ \\ ${ }^{1}$ Epidemiology Department, Faculty of Public Health, Airlangga University, Surabaya, Indonesia \\ Correspondence Address: Vidya Tri Huttami \\ Email: vidya.t.h26@gmail.com
}

\begin{abstract}
The 2007 Basic Health Survey shows the highest number of deaths in Indonesia rural and urban areas was caused by stroke. In 2007-2013, the stroke prevalence in productive age increased up to 22\%o. Stroke that attacks productive age can impair individual's ability to do activities, and thus they might have family financial constraint. Disabilities can be prevented and minimized if patients utilize a golden period of an ischemic stroke. This study identified the utilization of golden period of ischemic stroke in patients and analyzed causes of delayed patient admission to the Neurology Clinic of Sidoarjo Hospital. This study was a descriptive study conducted to 39 poststroke ischemic patients in productive ages under further therapy at the Neurology Clinic of Sidoarjo Hospital in 2016. The data were collected through interview from January-February 2017. The results present $62 \%$ of stroke ischemic patients utilized the golden period of a ischemic stroke. The average respondents' admission took 29.87 \pm 47.46 hours after patients experienced first stroke ischemic attacks (ranging from 1-168 hours). The respondents were admitted to the hospital late or $>4.5$ hours after the stroke attacks because most of them did not know stroke signs and symptoms. Therefore, hospitals or health care providers have to provide counseling service to patients and family members about stroke signs and symptoms, as well as the importance of early admission for treatment as soon as patient gets the first stroke attack.
\end{abstract}

Keywords: utilization of the golden period, ischemic stroke, productive age.

\begin{abstract}
ABSTRAK
Kematian tertinggi di wilayah pedesaan dan perkotaan Indonesia berdasarkan hasil Riskesdas Tahun 2007 disebabkan oleh stroke. Pada Tahun 2007-2013 prevalensi stroke usia produktif mengalami pengingkatan sebesar 22,2\%o. Stroke yang menyerang usia produktif dapat menyebabkan terganggunya ekonomi keluarga dikarenakan kecacatan setelah terjadinya serangan stroke. Kecacatan dapat dicegah dan diminimalkan jika pasien memanfaatkan golden period stroke iskemik. Penelitian ini bertujuan untuk mengidentifikasi pemanfaatan golden period oleh pasien stroke iskemik dan untuk menganalisis penyebab terjadinya keterlambatan pasien datang ke rumah sakit. Penelitian ini merupakan penelitian deskriptif pada 39 pasien pasca stroke iskemik di usia produktif yang mendapatkan pemeriksaan lanjutan di Poli Syaraf RSUD Sidoarjo. Pengambilan data dilakukan dengan cara melakukan wawancara pada pasien pasca stroke iskemik di usia produktif pada bulan Januari-Februari Tahun 2017. Hasil dalam penelitian ini menunjukkan bahwa $62 \%$ memanfaatkan golden period penanganan

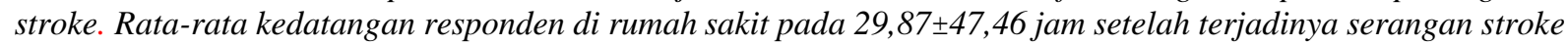
iskemik (range 1-168 jam). Responden yang datang ke rumah sakit terlambat atau >4,5 jam setelah serangan stroke dikarenakan sebagian besar responden tidak mengetahui tanda dan gejala penyakit stroke. Diharapkan rumah sakit atau tempat pelayanan kesehatan memberikan penyuluhan mengenai tanda gejala stroke pada pasien dan anggota keluarganya, serta pentingnya datang ke rumah sakit lebih awal setelah terjadi serangan stroke.
\end{abstract}

Kata kunci: pemanfaatan golden period, stroke iskemik, usia produktif

\section{INTRODUCTION}

Stroke occurs because of damage in blood circulation in the brain, causing brain tissue dead (Batticaca, 2008). Stroke becomes the third deadliest disease in the world compared to heart disease and cancer. Every year, 15 million people worldwide suffer from a stroke. Among them, 5 million people died, and another 5 million suffered from permanent disabilities which possibly burden families and community. Whereas in developing countries, stroke cause at least nearly 6 million deaths each year (WHO, 2002).

In Indonesia, stroke is the first cause of most deaths in urban and rural areas. The proportion of deaths due to stroke was $19.4 \%$ in urban areas and $16.1 \%$ in rural areas (MOH RI, 2008). The prevalence of 
stroke in Indonesia had increased from 8.3 per 1,000 people in 2007 to 12.1 per 1,000 people in 2013. East Java province had the fourth highest stroke prevalence among other Indonesian provinces as many as 16 per 1,000 people (MOH RI, 2013)

Based on the 2012 Health Profile of East Java, stroke was among the ten most common disease in patients under outpatient and inpatient care at type-B hospitals. For example, Sidoarjo District General Hospital reported stroke became the top 10 causes of deaths in 2014-2015. In 2014 , ischemic stroke was the fourth major cause of deaths at the hospital with the prevalence of $10.10 \%$. Then in 2015 , it increased to $14.9 \%$ of deaths.

Strokes can occur in any ages from newborns to elderly. The disease incidence increases as people get older (Anies, 2006). In the past, stroke only affected elderly, but now this disease tends to increase in productive ages, even under the age of 45 years. The 2013 Basic Health Research shows the prevalence of stroke in productive ages (15-64 years) was 62.6 per 1,000 people. As stroke attacks young people in productive ages, they can have lower productivity and family financial distress (Yulianto, 2011).

Early patient admission to a hospital for patients who experience stroke signs and the quality of the initial treatment are detrimental to the number of disabilities patients will have later. The golden period or golden hour is a certain period patients with stroke can use to decide an appropriate treatment. Medications carried out during the golden period can increase the likelihood of a stroke recovery (Adiati, T., Wahjoepramono, 2010). The earlier patietns are admitted to a hospital for treatment, the better the prognosisis, thereby lowering the possibility of disabilities suffered later (Nadesul, 2011). Based on the European Cooperative Acute Stroke Study (ECASS III), the golden period of administration of intravenous thrombolysis therapy is less than 3-4.5 hours after patients experience stroke (Hacke, W., et.al 2008).

Surveys in sever,al Asian countries show that most patients in Indonesia were admitted late to the hospital. They mostly spend six hours to a week for hospital admission as they try alternative medicine (Sutrisno, 2010). Whereas approximately one-third of respondents were admitted to a hospital more than 24 hours after patients got stroke. The respondents were unaware of mild stroke signs and symptoms.

By pointing out the stroke prevalence in Indonesian community, this study aimed to identify to which extent patients use the golden period of ischemic stroke and to analyze causes of hospital admission among stroke patients.

\section{METHODS}

This study was descriptive and collected data from January to February at the Neurology Clinic of Sidoarjo Hospital District in 2017. These study's samples were 39 ischemic stroke respondents in productive age (15-64 years) who could communicate well.

These study's variables involved patients' characteristics (gender, age, education, current occupation, family income, use of health insurance, and type of health insurance), the number of stroke attacks, time span between stroke warning sign and the time of hospital admission, utilization of golden period of ischemic stroke, and factors affecting the utilization of the golden period.

The respondents wre then interviewed to give further information. Data obtained from the interview were processed, analyzed descriptively, and presented in a tabular or figure form.

\section{RESULTS}

\section{Respondents' Characteristics}

Respondents' characteristics include gender, age, education, occupation, family income, use of health insurance, and 
types of health insurance. The results show that the respondents were mostly male $(53.8 \%)$. The number of male respondents was not much different from that of female respondents $(46.2 \%)$.

Table 1. Characteristics of Respondents at the Neurology Clinic of Sidoarjo Hospital in 2016.

\begin{tabular}{|c|c|c|}
\hline Characteristics & $\mathbf{n}$ & $\%$ \\
\hline \multicolumn{3}{|l|}{ Gender } \\
\hline Male & 21 & 53.8 \\
\hline Female & 18 & 46.2 \\
\hline \multicolumn{3}{|l|}{ Age } \\
\hline 15-24 Years & 0 & 0 \\
\hline 25-34 Years & 1 & 2.6 \\
\hline 35-44 Years & 4 & 10.2 \\
\hline 45-54 Years & 10 & 25.6 \\
\hline 55-64 Years & 24 & 61.6 \\
\hline \multicolumn{3}{|l|}{ Education } \\
\hline Low (Elementary-Junior & 18 & 46.1 \\
\hline High School) & 14 & 35.9 \\
\hline $\begin{array}{l}\text { Intermediate (High } \\
\text { school) }\end{array}$ & 7 & 18.0 \\
\hline \multicolumn{3}{|l|}{ Higher (Bachelors) } \\
\hline \multicolumn{3}{|l|}{ Occupation } \\
\hline Housewife & 12 & 30.8 \\
\hline Unemployed & 17 & 43.6 \\
\hline Civil servant/ soldier/ & 1 & 2.6 \\
\hline police & 3 & 7.7 \\
\hline Private worker & 2 & 5.1 \\
\hline Entrepreneur & 4 & 10.2 \\
\hline \multicolumn{3}{|l|}{ Retiree } \\
\hline \multicolumn{3}{|l|}{ Family Income } \\
\hline Low $(<1.5$ million $)$ & 1 & 2.6 \\
\hline Medium (1.5-2.5 million) & 11 & 28.2 \\
\hline High (2.5-3.5 million) & 20 & 51.3 \\
\hline Very High (> 3.5 million) & 7 & 17.9 \\
\hline \multicolumn{3}{|l|}{ Use of Health Insurance } \\
\hline No & 8 & 20.5 \\
\hline Yes & 31 & 79.5 \\
\hline \multicolumn{3}{|l|}{$\begin{array}{l}\text { Types of Health } \\
\text { Insurance }\end{array}$} \\
\hline Government & 31 & 100 \\
\hline Private & 0 & 0 \\
\hline
\end{tabular}

Based on age, the respondents in the age range 55-64 years were more dominant $(61.6 \%)$. There was no respondent aged 1524 years. Only one respondent was aged 32 years, and one oldest respondent was 64 years old. Most respondents had elementary and junior high education $(46.1 \%)$, while only a few respondents had higher education(18.0\%).

This study further describes the respondents' current employment status. Most respondents did not work after they experienced stroke (43.6\%). The majority of the respondents were in the high-income status (IDR 2,500,000-3,500,000) (51.3\%). Most of them used health insurance issued by the government to get treatment from the hospital (79.5\%).

Table 2. Number of Stroke Attacks.

\begin{tabular}{lcc}
\hline $\begin{array}{c}\text { Number of } \\
\text { Stroke Attacks }\end{array}$ & $\mathbf{n}$ & $\boldsymbol{\%}$ \\
\hline 1 time & 36 & 92.3 \\
2 times & 2 & 5.1 \\
3 times & 1 & 2.6 \\
\hline Total & 39 & 100 \\
\hline
\end{tabular}

Explained in Table 2, almost all respondents $(92.3 \%)$ experienced stroke once.

Time span between stroke attack and the time of hospital admission

Table 3. Time span between stroke attack with time of hospital admission.

\begin{tabular}{lcc}
\hline $\begin{array}{c}\text { Time of hospital } \\
\text { admission }\end{array}$ & $\mathbf{n}$ & $\mathbf{\%}$ \\
\hline <4.5 Hours & 10 & 25.6 \\
1 Hour & 8 & 20.5 \\
2 Hours & 6 & 15.4 \\
3 Hours & 6 & 15.4 \\
>4.5-48 Hours & 4 & 10.2 \\
3-4 Days & 4 & 10.2 \\
5-6 Days & 1 & 2.6 \\
\hline 7-8 Days & 39 & 100 \\
\hline Total & & \\
\hline
\end{tabular}


Table 3 presents most respondents were admitted to the hospital in the first hour of stroke attack $(25.6 \%)$. The average admission duration was $29.87 \pm 47.46$ hours after the onset of stroke (range 1-168 hours). The longest hospital admission took about 7 days after the onset of a stroke.

\section{Utilization of Golden Period}

The utilization of stroke golden period can be observed from the time span between the time of stroke attack and and admission of hospital admission. Respondents were considered using the golden period if they were admitted to the hospital at $\leq 4.5$ hours after experiencing the first stroke attack.

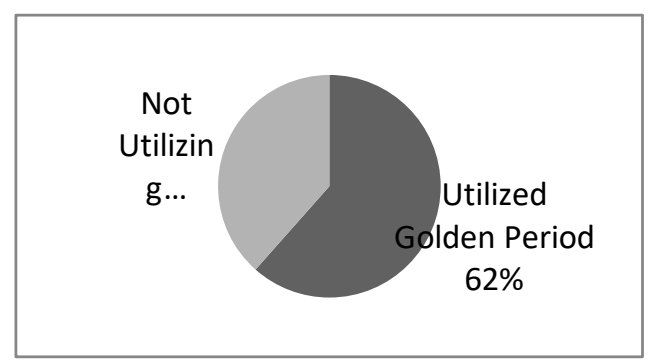

Figure 1. Utilization of Stroke Golden Period

Figure 1 shows that more than half of the respondents utilized the golden period to get the first treatment as soon as possible $(62 \%)$.

\section{Factors causing the utilization of golden period}

Patient admission outside the golden period (4.5 hours only after ischemic stroke attacks) did not use the time because of some factors explained in Table 4.

Table 4. Factors of Admission at $>4.5$ Hours.

\begin{tabular}{lcc}
\hline Factors & & Percentage \\
\hline $\begin{array}{l}\text { Patients cannot } \\
\text { identify }\end{array}$ & $9(60.0 \%)$ \\
signs & stroke & \\
Nobody can & $4(26.8 \%)$ \\
accompany patients & \\
\multicolumn{2}{l}{ to hospitals } & \\
\hline
\end{tabular}

\begin{tabular}{lrc}
\hline Factors & & Percentage \\
\hline $\begin{array}{l}\text { Patients are } \\
\text { willing to }\end{array}$ & $1(6.6 \%)$ \\
admitted & be & \\
hospitals & to & \\
$\begin{array}{l}\text { Patients } \\
\text { misdiagnosis at the }\end{array}$ & $1(6.6 \%)$ \\
first-level \\
healthcare facility
\end{tabular}

In Table 4, this study presents 15 respondents did not use the stroke golden period for seeking the first treatment $(60.0 \%)$ mostly because they could not identify the signs and symptoms.

\section{DISCUSSION}

\section{Respondents' Characteristics}

As seen in Table 1, post-stroke patients participating in this study were mostly males (53.8\%). Some studies show that men were more at risk of stroke compared to women (Wahyu, 2009). A man has a $25 \%$ higher risk of having a stroke at a young age than a woman (Stroke Association, 2016).

In line with this finding, the 2013 Basic Health Research finds in Indonesia the prevalence of stroke in men was higher but not much different from women. Based on the diagnosis of medical practitioners, men have stroke prevalence of 7.1 per 1,000 , while women have that of 6.8 per 1,000 . Similarly, Adawiyah, R., Kariasa, (2014) have found at Fatmawati Poli Neurology Hospital in Jakarta, the number of stroke male patients was more than that of females. The higher incidence of stroke in men can be caused by a higher unhealthy lifestyle, such as hypertension, smoking, and drinking alcohol.

One of the risk factors for stroke is age (Sari, et al., 2016). In this study, the respondents mostly suffered from stroke in the age range of 55-64 years $(61.6 \%)$. In Indonesia, most stroke sufferers are in the productive age group (Lumbantobing., 2007). Similarly, the 2013 Basic Health 
Research discovers an increase in the prevalence of stroke along with increasing age. The highest prevalence of stroke occurs at the age of 55-64 years. Age of 1524 years has stroke prevalence of 2.6 per 1,000 , and age of 25-34 years has prevalence of 3.9 per 1,000 . Additionally, age of $35-44$ years had stroke prevalence of 6.4 per 1,000 , while people in the age group of 45-54 years have stroke prevalence of 16.7 per 1,000. Finally, those in the age group of 55-64 year tend to have stroke prevalence of 33.0 per 1,000 people.

The Basic health Research also shows each increase in age will cause a greater risk of having stroke. When people in the productive age suffer from stroke, it is likely to result in economic distress on families. Yulianto (2011) mentions people with stroke may have a decline in productivity and financial difficulties after all. This is consistent with the results which indicate almost half of the respondents $(43.6 \%)$ did not work due to disabilities such as a paralysis. If the mortality and disability can be overcome, they might get back to work. To cope this problem, the government should have good, fast, and appropriate stroke management (Lumbantobing., 2007).

Education absolutely can bridge solutions for stroke management. This study find the respondents with stroke mostly had a low level of education (elementary-junior high school) (46.1\%). Brillianti (2016) in her study also find that most post-stroke patients had elementary education. The lack of education can affect people's lifestyle. Notoatmodjo (2007) further elaborates that people with more knowledge can shape better mindset and attitude, as well as behavior of healthy lifestyle. Lack of information about signs and symptoms will lead to susceptibility to various diseases, including stroke.

Wardhani, N. R., and Martini, (2014)supports the finding by saying the learning process is influenced by education. People with low education will be more difficult to receive information and vice versa.

The results also show most respondents with low education $(61.1 \%)$ did not use the golden period of stroke to seek for treatment. It poses as the result of insufficient knowledge about stroke signs and symptoms.

In addition to education, the incidence of stroke also affects occupation. This study shows that most of the respondents did not work after experiencing stroke (43.6\%). Although all respondents were in productive age, the majority did not work. Before the stroke attacked them, they still could work normally. Before the respondents got stroke, the majority of them had worked in private companies (10 respondents) and worked as entrepreneurs (4 respondents). However, they decided not to continue working as their health condition was not as fit as before.

Supporting this finding, Mahendra, B., and Rachmawati (2005) clarify disability is the most common effect of stroke limit patients to move. In particular, strict regulations of some companies do not allow people with stroke to take leave from work or some people come home to seek for someone who can take care of them. As a result, patients with stroke have more limitation in doing activities.

Most respondents with low education $(61.1 \%)$ did not make use of the golden period of stroke for seeking a treatment due to lack of knowledge about the disease symptoms. Immediate action in the golden period may reduce the impact or complications of stroke.

Analyzed from health insurance status, people can utilize health insurance to monitor their health status regularly just in case stroke attacks will recur. This study points out some respondents had recurrent strokes. Adawiyah, R andc Kariasa (2014) also find the majority of post-stroke patients who continued treatment at the hospital experienced the first stroke (69.4\%).

People should be alerted about recurring stroke since the attack might more 
fatal than the first attack. According to Pinzon, R and Laksmi, (2010), repeated strokes in the first year were found in $11.2 \%$ of cases. Therefore, it is important to mitiage risk factors which can be a major cause of recurring stroke, such as controlling hypertension, cholesterol, and smoking habits.

\section{Time span between stroke attack and the time of hospital admission}

Keeping us warned about stroke signs will ease more rapid patient admission to hospitals to seek for the first treatment. Table 3 shows most of the respondents were admitted in the first hour of stroke $\operatorname{attacks}(25.6 \%)$, with an average duration of $29.87 \pm 47.46$ hours. Not much different from the research conducted by Saver, et al., (2010), there were $27.1 \%$ of patients admitted within 60 minutes after the onset of symptoms, but more than $70 \%$ admitted outside the golden period. Such long patient admission can affect duration of drug administration and treatment patient will receive.

Treatment of R-tPA (recombinant tissue plasminogen activator) for patients with ischemic stroke is more effective if given in the first hour of stroke symptoms (Ebinger, et al., 2015). These antithrombolytic drugs can destroy thrombusthrombus that clogs in the blood vessels of the brain (Mahendra, B \& Rachmawati 2005). Not all patients admitted during the golden period can receive R-tPA treatment since they need to meet several criteria. Research at 905 hospitals that are members of the GWTG-Stroke (the Get With the Guidelines) shows $28.3 \%$ respondents admitted in $\leq 60$ minutes after the first stroke attack, while $31.7 \%$ came in $61-180$ minutes. The rest were admitted in $>180$ minutes. It means only $64.7 \%$ patients admitted in $\leq 60$ minutes received TPA injection more than the others (Saver, et al., 2010).

Fast patient admission will the patient will have a greater chance of receiving antithrombotic drugs for reducing consequences that come up later. Lutfie, (2012) said that fast and precise handling during the golden period can prevent the fatal effects of stroke. The longer people ignore stroke, the greater the brain damage can occur. Quick treatment for stroke may reduce $30 \%$ disabilities.

\section{Utilization of Golden Period of Stroke}

The utilization of the golden period of stroke can only be seen in people with ischemic stroke. Based on Table 1, more than half of the respondents $(62 \%)$ with ischemic stroke utilized the golden period to manage stroke signs and symptoms. The European Cooperative Acute Stroke Study (ECASS III) mentions ischemic stroke handling in the golden period takes less than 3-4.5 hours (Hacke, et al., 2008).

Even though more than half of the respondents were admitted within $\leq 4.5$ hours, many patient admissions exceeds the golden period. As a result, they probably did not receive this antithrombotic treatment. Saver, et al., (2010) states brain damage result in nearly 2 million nerve cells die. Decline in disabilities due to stroke may occur if patients are admitted to hospitals in the golden period. Early treatment in the golden period can stabilize the condition of patients and prevent morbidity and mortality rates due to stroke.

\section{Factors causing delay in patient admission}

It is likely to delay patient admission when patients are not aware of stroke signs and symptoms. This matter might be associated with insufficient knowledge of patients or their families. Therefore, families should be more aware of acting to get immediate help. In another circumstance, late patient admission occurred because of misdiagnosis. As a result, the respondents could not be immediately referred to get better treatment in more advanced health facility. Such misdiagnosis indicates that the healthcare facility did not apply quality control or 
improve quality of their services. Some healthcare providers are not capable of giving treatment to patients because they have limited facilities, equipment, or personnel, thereby referring the patients to more advanced health facility.

The respondents already used health insurance for accessing promotive, preventive, curative, and rehabilitative treatments. Similar to the results of Misbach's, (2001) research, patients with little knowledge of stroke signs and symptoms had delayed admission to hospitals. Some others still tried to find traditional treatment for curing their disease, and some had transportation difficulties.

\section{CONCLUSION}

More than half of the respondents took advantage of the golden period to get first treatment at hospital. The majority of respondents who were admitted late had poor knowledge of stroke signs and symptoms. Besides, they had nobody to help them visit the hospital. Some still had difficulty in finding transportation, were not willing to be treated at the hospital, and others got misdiagnosis that prolong referral to more advanced healthcare facilities.

InIt is important that all family members are aware of stroke signs and symptoms to act out just in case patients experience stroke attacks. It is expected that hospitals, especially nerve polyclinics can provide counseling about stroke signs and symptoms, as well as the utilization of the golden period in handling ischemic stroke and improve. First-level healthcare facilities should improve the quality of examinations, working together with health insurance agency, and provide training about stroke for staff.

\section{REFERENCE}

Adawiyah, R., Kariasa, I.M., 2014. Faktor faktor yang berhubungan dengan kualitas hidup pada pasien pasca stroke. Skripsi. Fakultas Ilmu Keperawatan. Universitas Indonesia. Adiati, T., Wahjoepramono, E., 2010. 171 Tanya Jawab tentang stroke. Jakarta: PT Gramedia.

Anies., 2006. Waspada Ancaman Penyakit Tidak Menular, Solusi Pencegahan dari Aspek Perilaku Dan Lingkungan. Jakarta: PT. Elex Media Komputindo.

Association., S., 2016. State Of The Nation Stroke Statistic.

Batticaca, F., 2008. Asuhan Keperawatan pada Klien dengan Gangguan Sistem Persyarafan. Jakarta: Salemba Medika.

Brillianti, P., 2016. Hubungan SelfManagement dengan Kualitas Hidup Pasien Pascastroke di Wilayah Puskesmas Pisangan Ciputat. Skripsi. Fakultas Kedokteran dan Ilmu Kesehatan. Universitas Islam Negeri Syarif Hidayatullah.

Indonesian Ministry of Health, 2008. Riset Kesehatan Dasar 2007, Jakarta.

Indonesian Ministry of Health, 2013. Riset Kesehatan Dasar 2013, . Jakarta.

Ebinger, M., Kunz, A., Wendt, M., Rozanki, M., Winter, B., Waldschmidt, C., et al., 2015. Effects of golden hour thrombolysis: a Prehospital Acute Neurological Treatment and Optimization of Medical Care in Stroke (PHANTOM-S) substudy. JAMA Neurology, 72(1), pp.25-30. https://doi.org/10.1001/jamaneurol.2 014.3188

Hacke, W., Kaste, M., Erich, B., Miroslav, B., Antoni, D., Donata, G., et al., 2008. Thrombolysis with alteplase 3 to 4,5 hours after acute iskemik stroke. The New England Journal of Medicine, 59(13), pp.1313-1329.

Lumbantobing., 2007. Stroke bencana peredaran darah di otak. Jakarta: Badan Penerbit FK-UI.

Lutfie, S.H., 2012. Kembali aktif pasca stroke, panduan terapi mandiri penderita stroke di rumah. Solo: 
Metagraf.

Mahendra, B., Rachmawati, E., 2005. Atasi Stroke dengan tanaman obat. Jakarta: Penebar Swadaya.

Margaret, J.S., Loria, G., 2013. Early management of acute ischemic stroke cases (Acute Stroke Protocols \& Guidelines/Algorithms) @ Apollo Hospitals, Hyderabad. Apollo Medicine IO. https://doi.org/10.1016/j.apme.2013. 11.002

Misbach, J., 2001. Pattern of hospitalizedstroke patients in ASEAN countries an ASNA stroke epidemiological study. Med J Indones, 10(1), pp.4856.

https://doi.org/10.13181/mji.v10i1.6

Nadesul, H., n.d. Menyayangi Otak, menjaga kebugaran, mencegah penyakit, memilih makanan. Jakarta: Kompas.

Notoatmodjo, S., 2007. Pendidikan dan Perilaku Kesehatan. Jakarta: PT Rineka Cipta.

Pinzon, R., Laksmi, A., 2010. Awas Stroke!Pengertian, Gejala, Tindakan, Perawatan dan Pencegahan. Yogyakarta: Andi Offset.

Sari, W., Lili, I., Catur, S., 2016. Care Your Self, Stroke cegah dan Obati Sendiri. Jakarta: Penebar Plus.

Saver, JL., Eric, ES., Greg, C., Fonarow., Mathew, JR., Xin, Z., et al., 2010. The "golden hour" and acute brain ischemia presenting features and lytic therapy in $>30.000$ patients arriving within 60 minitus of stroke onset. AHA Journals., 41, pp.14311439.

https://doi.org/10.1161/STROKEAHA .110 .583815

Sutrisno, A., 2010. Stroke?You Must Know Before You Get It!. Jakarta: PT Buana Printing.

Wahyu, G.G., 2009. Stroke hanya menyerang orang tua?. Yogyakarta: PT. Bentang Pustaka.

Wardhani, N. R., Martini, S., 2014. Faktor yang berhubungan dengan pengetahuan tentang stroke pada pekerja institusi pendidikan tinggi. Jurnal Berkala Epidemiologi., 2(1), pp.13-23.

$\mathrm{WHO}, 2002$. The atlas of heart disease and stroke.

Yulianto, A., 2011. Mengapa Stroke Menyerang Usia Muda?. Jakarta: PT. Buku Kita. 